\title{
Discussion
} Papers

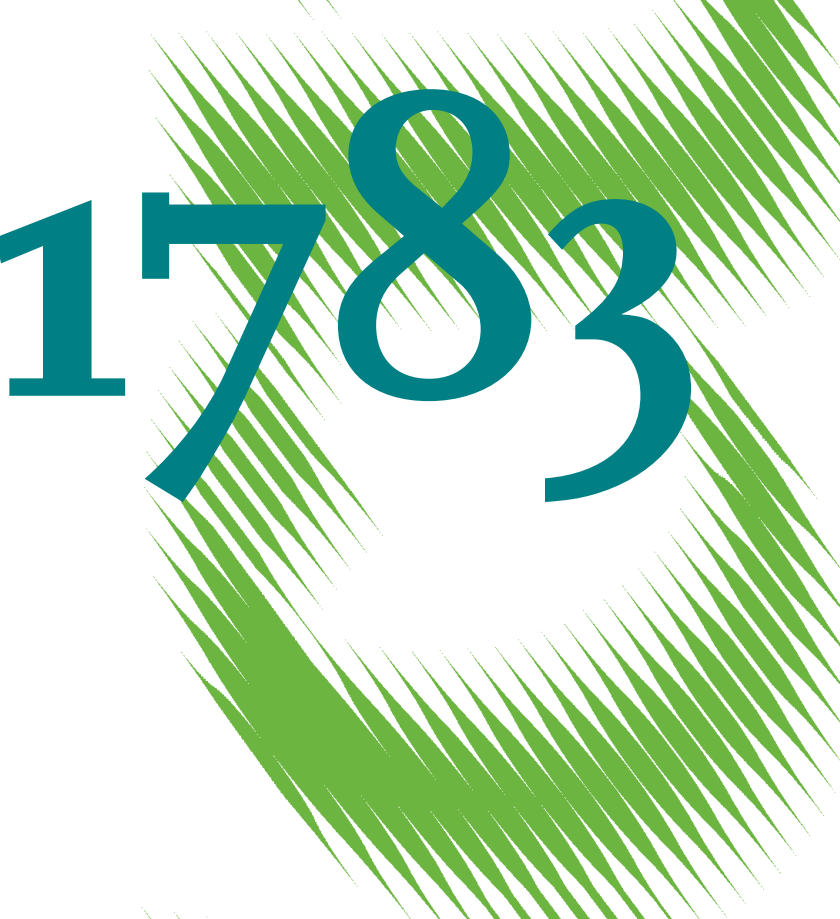

Where Does the Fairtrade Money Go? How Much Consumers Pay Extra for Fairtrade Coffee and How This Value Is Split along the Value Chain 
Opinions expressed in this paper are those of the author(s) and do not necessarily reflect views of the institute.

IMPRESSUM

(C) DIW Berlin, 2019

DIW Berlin

German Institute for Economic Research

Mohrenstr. 58

10117 Berlin

Tel. +49 (30) $89789-0$

Fax +49 (30) $89789-200$

http://www.diw.de

ISSN electronic edition 1619-4535

Papers can be downloaded free of charge from the DIW Berlin website:

http://www.diw.de/discussionpapers

Discussion Papers of DIW Berlin are indexed in RePEc and SSRN:

http://ideas.repec.org/s/diw/diwwpp.html

http://www.ssrn.com/link/DIW-Berlin-German-Inst-Econ-Res.html 


\title{
Where does the Fairtrade money go? \\ How much consumers pay extra for Fairtrade coffee and how this value is split along the value chain
}

\author{
Helene Naegele*
}

January 16, 2019

\begin{abstract}
Fairtrade certification aims at transferring wealth from the consumer to the farmer; however, coffee passes through many hands before reaching final consumers. Bringing together retail, wholesale, and stock market data, this study estimates how much more consumers are paying for Fairtrade-certified coffee in US supermarkets and finds estimates around $\$ 1$ per lb. I then assess how this price premium is split between the different stages of the value chain: most of the premium goes to the roaster's profit margin, while the retailer surprisingly makes smaller absolute profits on Fairtrade-certified coffee, compared to conventional coffee. The coffee farmer receives about a fifth of the price premium paid by the consumer, but it is unclear how much of this (quantity-dependent) benefit goes toward the payment of (quantity-independent) license fees.
\end{abstract}

JEL codes: L15, L31, L66, O13, Q01.

Keywords: Coffee, Fairtrade, Price premium, Value chain, Voluntary sustainability standards.

*I would like to thank Pio Baake, Jana Friedrichsen, Anna Lu, Johanna Mollerstrom, Hannes Ullrich, Céline Bonnet, Zohra Bouamra-Mechemache, Lucie Botega, Stephane Caprice and Marion Desquilbet, as well as seminar participants at DIW Berlin and Toulouse School of Economics for helpful discussions. Jana Hamdan provided excellent research assistance. I would also like to thank Parker Townley from Fair Trade USA, Michael W. Kruger from IRI, and Andrew Rumpelt from NatPromo for helping me with data. I thank IRI for making the data available. All estimates and analysis in this paper, based on data provided by IRI are by the author and not by IRI. Financial support by the Leibniz Competition through the project GlobalFood (SAW-2015-DIW-4) is gratefully acknowledged. DIW Berlin, Mohrenstrasse 58, 10117 Berlin, Germany. hnaegele@diw.de, +49-30-89789-518. 
Fairtrade labels provide consumers with the possibility to make a donation to farmers via the purchase of a product. This Fairtrade system is part of a larger trend based on the increasing interest of consumers for the ethical background of their consumption. The coffee market is notorious for the extreme poverty of many of its farmers. Coffee prices are volatile and, in many years, so low they do not even cover the costs of small-scale farmers (e.g. Fair Trade USA 2017b). Unsurprisingly, voluntary sustainability standards (VSS) addressing sustainability concerns are particularly prevalent on this market.

The present study concentrates on the largest label for social sustainability: the Fairtrade 1 label as established by FLO International and Fair Trade USA. The Fairtrade label addresses poverty concerns by guaranteeing a fair price for coffee growers, composed of a minimum price and a social premium. In order for a product to be sold with the label, the producer (farmer cooperative), the exporter (typically an international commodity trading firm), and the roaster (national or multinational consumer brands) have to be certified by the Fairtrade organization.

For roasters and retailers, the Fairtrade label is also a tool to segment the market and skim the consumer's increased willingness-to-pay for Fairtrade-certified coffee. Both the retail market and the consumer brands that roast and package coffee are highly concentrated. Packaged coffee is a differentiated good with considerable profit margins. The split of value added between manufacturers and retailers depends on how the Fairtrade label affects their relative market power.

Consumers buy Fairtrade-certified coffee in the supermarket in order to help poor farmers, but the money has to travel through the entire coffee value chain. This raises the question about the efficiency of the transfer: how much do consumers pay extra for Fairtrade-certified coffee? How much of this transfer goes to the farmer? Who receives the remaining portion of this transfer?

This study measures how much consumers pay more in US supermarkets from 2010 to 2012 for Fairtrade-certified coffee using hedonic price regressions and finds estimates around $\$ 1$ per lb (ranging from $70 c$ to $\$ 2$ per lb). This price premium paid by the consumer for the Fairtrade label is higher than the price premium received by the farmer cooperative, which is around $21 c$ per $\mathrm{lb}$ for the 2010 to 2012 period. Where does the additional value go? This study brings together information on retail, wholesale and farmer prices and uses the similarity between Fairtrade and conventional 2 coffee production process, to estimate how the price premium for the consumer is split along the vertical value chain. I find that most of the manufacturer margin increases by more than $\$ 1$, while retailers make smaller margins on Fairtrade-certified products compared

\footnotetext{
${ }^{1}$ Throughout this text "Fairtrade" refers to the FLO and Fair Trade USA labels, not to the general (philosophical) concept of fair trade. To avoid confusion, Figure 7 in the Appendix shows the logos discussed.

${ }^{2}$ Throughout this study, I refer to non-Fairtrade-certified coffee as "conventional", in analogy to the opposition between organic and non-labeled products, called conventional.
} 
to similar non-labeled products.

After giving extensive background information on the coffee market and the Fairtrade label (Section 1), I describe my data. Extensive descriptive statistics give an overview of the US market for ground coffee (Section 2). I then determine the price premium associated with Fairtrade certification for the consumer (Section 3) and examine how this price premium is split along the stages of the coffee value chain (Section 4).

\section{Background information and literature}

This section first describes the coffee value chain, which is similar for Fairtrade-certified and conventional coffee. I then explain the Fairtrade system, in particular its price rules. I finish with an overview of the literature on three aspects: How do consumers think about the Fairtrade label? What impact has the Fairtrade label on the farmer? How does Fairtrade impact profit-sharing along the vertical value chain?

\subsection{Coffee value chain}

The typical coffee value chain starts with a producer (farmer), who can be anything between a small-scale farmer and a plantation with large numbers of hired workers. Smallscale farmers often do not sell directly, but rather via a cooperative, as the coffee cherries must be peeled and dried to be transformed into green beans before shipping and this requires equipment investments that are not viable for individual small-scale farmers.

These producers sell to trading firms, which are highly concentrated around the globe and often trade many food commodities, e.g. Olam International, Louis Dreyfus Group, Volcafe. Commodity-grade green coffee is traded on stock exchanges, and more expensive higher-quality grades, organic certified, and specialty coffee contracts are typically indexed on this stock exchange price. The traders then ship green coffee to the coffee manufacturer (roaster) in the consuming country.

The roaster then roasts and packages the beans, transforming the commodity into a branded, finished consumer good. The consumer market for ground coffee is an oligopoly market with strong brands, achieving high retail prices (Bettendorf and Verboven 2000). For the coffee roasting brands, coffee is a product with an unusually high cost share of the main input (green beans) and a simple production function that uses beans, packaging, energy, and labor in fixed proportions. Some coffee is processed into instant coffee or caffeine powder as input for other products, while some is sold as brewed coffee in catering, but this study does not consider these markets. The coffee is then sold to retail stores, which in many countries are organized in highly concentrated retail chains.

Despite the importance of green beans as the main input for the production process, the pass-through between highly volatile coffee commodity prices and stable retail prices is 
low: Nakamura and Zerom (2010) build a menu cost model of oligopolistic price-setting by the manufacturers to explain delayed and incomplete pass-through. They find that menu costs play a small role when compared to local costs and mark-up adjustments. Similarly, Bettendorf and Verboven (2000) explain the low pass-through with the importance of local costs, which account for about $40 \%$ of total marginal cost. In their estimation, small mark-up reductions in reaction to bean price play a minor role. Feuerstein (2002) proposes two models of the coffee market showing that roasters do not always benefit of low input prices, depending on market structure.

Historically, international coffee trade was shaped during the Cold War period by the International Coffee Agreement (ICA) which gave producing countries the possibility to set quotas to stabilize prices at a high level (Akiyama and Varangis 1990). The ICA was, in practice, a tool to transfer resources to producing countries allied to the Western world: about half of total income from coffee went to these producing countries, with most of this going to national governments rather than coffee farmers (Talbot 2004). After the collapse of the ICA system in 1989, the income of producer countries immediately fell by about $85 \%$ Johannessen and Wilhite 2010). Since then, prices have become more volatile and concerns about the viability of small-scale coffee farming are increasing (e.g. Ponte 2002).

\subsection{Fairtrade labeling system}

Throughout the 20th century, there have been calls for "fairer trade" and initiatives to support the living standard of farmers in developing countries. In 1988, the Max Havelaar organization was founded in the Netherlands, generally recognized to be the first Fairtrade labeling organization. Soon, similar national organizations were founded in other industrialized countries, like TransFair Deutschland, Trans Fair USA, Max Havelaar France. In 1997, these national organizations founded an umbrella organization, Fairtrade Labeling Organization International (FLO), which today defines and updates the standards catalog not only for coffee but many other commodities (see e.g. Johannessen and Wilhite 2010 for more details).

While the early fair trade movement was selling products in specialized "world shops," the current Fairtrade labeling system is characterized by the decision to cooperate with mainstream retailers and manufacturers. The non-profit organization FLO (resp. Fair Trade USA for the USA) sets a standards catalog and the third-party certification company FLO-Cert GmbH (resp. SCS Global Services, Inc.) audits certified farmers and manufacturers and distributes the license to use the label. Neither the non-profit standard setter nor the third-party certifier buys, roasts, or sells any coffee.

The main selling point of Fairtrade-certified coffee is the "fair producer price" that 


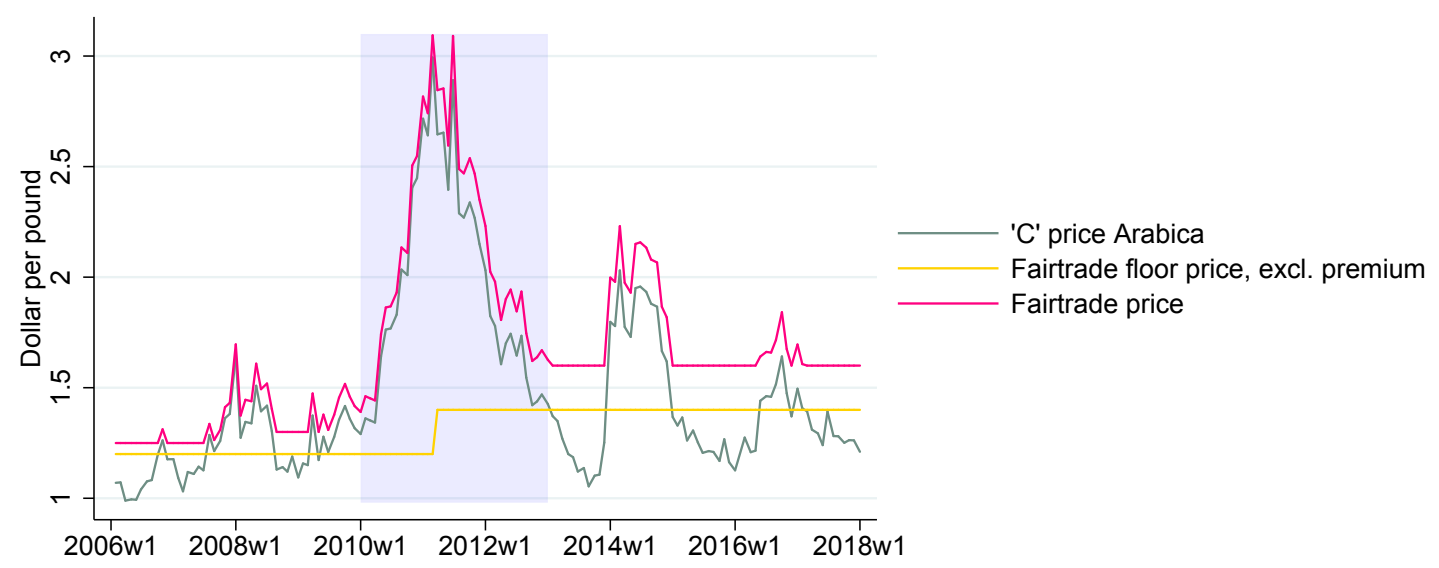

Figure 1: Prices of conventional and Fairtrade-certified Arabica coffee, time period of this study is shaded in blue

Source: "C" coffee future from www.investing.com consulted on October 1, 2018; Fairtrade documentation on www.fairtrade.net own computations.

is given by the maximum between the Fairtrade minimum price of $\$ 1.40$ per $1 b^{3}$ and the market price, given for Arabica by the "C" contract on the New York stock exchange. In addition to raising the price level, such a minimum price rule reduces volatility. To put this price into perspective, note that the target price range of the ICA for 1980 to 1989 was 1.20-1.40\$ per lb (Akiyama and Varangis 1990), which in current 2018 US dollars is equivalent to $\$ 2.44-2.84$ per $1 b \sqrt{4}$ Additionally, cooperatives receive a social premium of $\$ 0.20$ per lb of coffee sold under the Fairtrade label. ${ }^{5}$ Cooperatives should invest this social premium "in the producers' business, livelihood, and community." 6 . Typically, cooperatives invest in processing facilities, schools and training; sometimes they just "distribute the money as an income supplement" (Parrish et al. 2005).

Figure 1 shows the conventional and Fairtrade-regulated price for Arabica coffee, the period used in this study appears in light blue on the figure. Up to 2007, world prices are mostly below the Fairtrade floor price, then prices hugely increase between 2008 and 2013 and are mostly above the Fairtrade floor price. Between 2013 and 2017, the world market prices oscillate again around the Fairtrade floor price.

Besides the price rules, Fairtrade stipulates that buyers must provide long-term contracts as well as pre-harvest advance payments. Additionally, the Fairtrade standards cover organizational details, environmental problems, fertilizers, working conditions, and child labor. However, often these other dimensions are not mandatory for participating

\footnotetext{
${ }^{3}$ Floorprice price valid for washed green Arabica FOB in 2018. All prices in $\$$ refer to nominal United States dollars, not corrected for inflation. The Fairtrade floor price aims at protecting farmers against low world prices. The floor price is infrequently updated: from the beginning until April 2011, the floor price was $\$ 1.21$ per lb.

${ }^{4}$ Adjustment for CPI inflation from 1989 to 2018 using www.bls.gov/data/inflation_calculator.htm. consulted on January 6, 2019.

$5 \$ 0.10$ per lb before April 1st, 2011; and $\$ 0.05$ per lb before January 2008.

6 www.flocert.net/glossary/Fairtrade-premium/; consulted on October 1, 2018.
} 
cooperatives $]^{7}$ Initially, Fairtrade labeling for coffee was restricted to small-scale farmers. In order to extend the reach of Fairtrade, Fair Trade USA wished to make the certification available to plantations, i.e. large farms relying on employed labor. As the FLO rejected this idea, Fair Trade USA left the FLO umbrella organization in January $2012^{8}$ and pursued its initiative "Fairtrade for All" ${ }^{9}$ focusing on growth and including large coffee plantations. Although they are now separate institutions, all other aspects of the standard endorsed by Fair Trade USA and the other FLO members remain remarkably similar; in particular, the floor price for coffee is identical. Fair Trade USA effectively recognizes FLO certification, i.e. the farmer base of Fair Trade USA includes all FLO-certified cooperatives plus Fair Trade USA-certified plantations.

The production of Fairtrade coffee is increasing, with $13 \%$ compound annual growth worldwide 2008-2012 (Potts et al. 2014). Coffee is a market with a large proportion of Fairtrade sales, nevertheless the global market share remains small: the worldwide market share of Fairtrade-certified coffee in 2012 is $1.6 \%$ (Potts et al. 2014). In my data on US retailing, the Fairtrade market share is $2.5 \%$ in 2012.

\subsection{Fairtrade and the consumer}

The literature finds consistently that consumers are willing to pay a premium for the Fairtrade label (Loureiro and Lotade 2005, Basu and Hicks 2008, Didier and Lucie 2008), and debates whether this willingness-to-pay arises from altruism, "warm glow" (Andreoni 1989), or social image concerns (Friedrichsen and Engelmann 2018, Teyssier et al. 2014). In a large field experiment in US supermarkets, Hainmueller et al. (2015) find that at constant prices, the Fairtrade label increases sales by $10 \%$; when they vary prices, they see that consumers have heterogeneous price elasticities.

From a theoretical standpoint, Fairtrade coffee is a product bundled with a donation. However, Reinstein and Song (2012) state that consumers should only be willing to bundle two things if the bundling yields additional efficiency. In their model, this efficiency arises from a moral hazard problem on quality, overcome by the consumer's altruism. Such bundling also occurs in "green goods" such as carbon-neutral flights or recycled paper, for which Munro and Valente (2016) show that bundling a private good with a small public good reduces pro-social behavior; as an explication, the authors invoke evidence from social psychology on anchoring and reluctant altruism, even in a situation where

\footnotetext{
7 Fair Trade USA (2017a) details the requirements for certification by Fair Trade USA, where the organization defines minimum and progress requirements, where the latter are not mandatory. The document for example states "workers receive fair wages," which translates into one mandatory criterion: "Salaries and wages are in line with or exceed legally mandated minimum wages for the job." The large majority of environmental criteria is not mandatory.

8 https://fairworldproject.org/fair-trade-usa-splits-from-flo-joint-announcement-from-Fairtradeinternational-and-fair-trade-usa/; consulted on October 1, 2018.

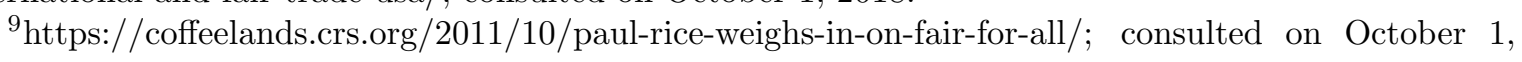
2018.
} 
the availability of the green good should theoretically not affect the consumer choice.

Combining aggregate data on Fairtrade prices and quantities and international estimates for the Fairtrade premium paid by the consumer, Gingrich and King (2012) find that consumers spend between $\$ 4$ and $\$ 11$ for transferring $\$ 1$ to the farmer in social premium 10 Using panel data methods on price changes when existing products become Fairtrade-certified, Carlson (2008) finds that consumers pay a much smaller Fairtrade price premium of $12 c$ per product, but he does not compute how this premium translates into farmer revenue.

\subsection{Fairtrade and the farmer}

Despite its great success among consumers, the Fairtrade system seems to be fundamentally flawed: farmer cooperatives indeed achieve a higher price per pound of Fairtradecertified coffee, but nothing in the FLO system guarantees them that they will be able to sell all of their production with the label. Since 2004, farmers pay auditing and licensing fees (Janvry et al. 2015). These fees are typically a function of cooperative size, but are not proportional to quantities produced or sold, cf. for more information www.fairtrade.net. In a concise theoretical model, Janvry et al. (2015) show that a system with variable, i.e. proportional to sold quantity, rents and fixed entry costs has a unique equilibrium where the number of certified cooperatives is such that expected benefits (Fairtrade premium times quantity sold under the label) equal certification costs (fixed fee incurred once a year toward the certification body). Empirically, the supply of potentially Fairtrade-certified coffee hugely exceeds demand: Janvry et al. (2015) find that certified farmers sell on average $22 \%$ of their production under the label, a share varying between $13 \%$ and $28 \%$ depending on world market prices; Valkila and Nygren (2010) find shares between 30 and $60 \%$; in worldwide aggregate data by Potts et al. (2014), Fairtrade-certified farmers sell $30 \%$ of their 2012 production at Fairtrade prices. Fundamentally, Fairtrade labels are a "disequilibrium tool" (Janvry et al. 2015) that fixes prices, but lets quantities be decided by the market: as Smith (2010) puts it, the current Fairtrade certification system fails by trying to be "in and against the market" simultaneously.

The early empirical literature on Fairtrade is mostly based on qualitative case studies, while newer quantitative literature controls for selection into Fairtrade certification (cf. Dragusanu et al. 2014 for an extensive literature review). While many agree that Fairtrade certification is probably not random, the literature is divided between finding positive selection, i.e. more experienced and better organized cooperatives are certified, and negative selection, i.e. Fairtrade labels give cooperatives with low quality the possibility to achieve a premium price.

\footnotetext{
${ }^{10}$ Some alternative fair trade initiatives adopt this logic, explicitly stating the amount and percentage share received by the farmers, e.g. Transparent Trade Coffee www.transparenttradecoffee.org/transparentcoffees consulted on October 1, 2018.
} 
The empirical literature controlling for selection typically finds that the higher Fairtrade price does not automatically lead to higher income and lower poverty rates. Valkila and Nygren (2010) find that Fairtrade has no impact on farmer income, arguing that low prices are not the problem, but rather the low productivity of small-scale farmers; Ruben and Fort (2012) show the importance of accounting for selection and find that matching reduces the effect size dramatically, leaving only a modest impact of Fairtrade certification on income ${ }^{11}$ Sáenz Segura and Zúñiga-Arias (2008) find that the positive impact of Fairtrade on annual income is "not observable"; Van Rijsbergen et al. (2016) find Fairtrade-certified farmers have significantly smaller gross incomes. Dramatically, Beuchelt and Zeller (2011) find that over a 10-year window the Fairtrade-certified farmers have become poorer relative to non-certified farmers. Research by Fair Trade USA (2017b) itself finds that current price levels for Fairtrade-certified coffee are not high enough to guarantee long term economic sustainability if opportunity costs are taken into account. Indeed, the effect of Fairtrade on farmer lives seems so small, that many farmers are not aware that they are themselves part of a Fairtrade-certified cooperative (Valkila and Nygren 2010, Johannessen and Wilhite 2010). Chiputwa et al. (2015) find a positive income effect; however, it is difficult to disentangle the effect of the Fairtrade label from the fact that the only Fairtrade cooperative in their data sells green beans, while other Ugandan resellers sell sun-dried cherries, i.e. a less processed good. Dragusanu and Nunn (2018) find a small, but positive effect of Fairtrade certification on sales, prices, and farmer revenue using a difference-in-differences methodology.

Parrish et al. (2005) ask whether Fairtrade is the most efficient way of transferring money to farmers. They compare the impact of Fairtrade with the effect of technical and organizational training by a non-governmental organization (TechnoServe) in Tanzania. Minten et al. (2018) compare Fairtrade with the Productive Safety Net Program (PSNP) in Ethiopia, for which it was estimated that beneficiaries received $80 \%$ of the program funds.

While the majority of studies finds that Fairtrade certification has at best a modest effect on farmer income, some studies find that the certification has other benefits: indeed, the social premium earmarked for community investment might solve coordination problems on the provision of public goods for the farming community. For example, the premium can be used to finance schools, infrastructure like processing facilities, and farmer trainings. Dragusanu and Nunn (2018) find that in Costa Rica, regions with a higher share of Fairtrade-certified cooperatives have higher schooling rates. Gitter et al. (2012) find a similar effect, especially for girls in Southern Mexico.

Moreover, as an additional requirement of the certification, Fairtrade commodity

\footnotetext{
${ }^{11}$ It however stands to debate what drives this modest, but significantly positive effect of Fairtrade on animal livestock and agricultural assets: in the data of Ruben and Fort (2012), Fairtrade farmers have a lower per-hectare yield and sell their coffee at identical prices as non-certified farmers.
} 
traders should provide pre-harvest credit to cooperatives. The literature is divided on how well this works in practice: Ruben and Fort (2012) find that Peruvian Fairtrade-certified farmers have significantly better access to credit, while Van Rijsbergen et al. (2016) fail to find such an effect. Valkila and Nygren (2010) show that in Nicaragua cooperatives are among the main source for pre-finance for farmers, but the Fairtrade-certified cooperatives give less advantageous interest rates 12 The German Fairtrade organization claims that all external studies concentrate on specific aspects of Fairtrade and thus fail to do justice to the complexity of the Fairtrade standards 13

\subsection{Fairtrade along the value chain}

In this study, the value chain of coffee is simplified to its three crucial steps: farmer cooperatives sell green beans to manufacturers via international traders; manufacturers transform the beans into roasted coffee and sell it to retailers; retailers sell the packaged good to final consumers. Transaction prices for green beans are indexed on international stock markets (more details in the data section) and the beans are a largely homogeneous good, so that individual farmer cooperatives have virtually no market power. The Fairtrade price depends on the Fairtrade rules and the market price of conventional coffee, so it is not a result of demand and supply for Fairtrade coffee. In contrast, roasted branded and packaged coffee is a differentiated good, and retailers and manufacturers both have market power. The wholesale prices are likely to result from the bargaining between manufacturers and retail chains. Fairtrade-certified and conventional coffee are often sold by the same manufacturers and retailers.

Draganska et al. (2010) propose a model of bargaining between multi-product manufacturers and retail chains, where the wholesale price maximizes the "generalized Nash product" of manufacturers and retailers. For each differentiated good, this Nash product is the product of each negotiator's gains from trade (profits with the good minus profits without the good) weighted by their bargaining power. ${ }^{14}$ The deviation profits (profits without the good) are endogenous to the model, while bargaining power is an exogenous characteristic depending, for example, on negotiation skills, information structure, or differences in time preferences. Bonnet and Bouamra-Mechemache (2016) empirically apply this model to the French milk market and finds that organic brands have a higher bargaining parameter $\lambda$, so the label shifts profits from the retailer to the manufacturer.

\footnotetext{
${ }^{12}$ In the data of Valkila and Nygren (2010) on Nicaragua in 2005/2006, export companies charged $11 \%$ p.a. for credit, while Fairtrade-certified cooperatives charged interest rates between $18 \%$ and $22 \%$ p.a.

${ }^{13}$ TransFair e.V. in private communication; December 4, 2018.

${ }^{14}$ Formally, for good $j$ the Nash product is defined as $\left(\pi_{j}^{r}\left(p_{j}^{w}\right)-d_{j}^{r}\right)^{\lambda}\left(\pi_{j}^{m}\left(p_{j}^{w}\right)-d_{j}^{m}\right)^{1-\lambda}$, where $\pi_{j}^{r}$ and $\pi_{j}^{m}$ are the profits to the retailer and the manufacturer if the negotiations succeed, $d_{j}^{r}$ and $d_{j}^{m}$ are the disagreement pay-offs obtained if the negotiations fail and $p_{j}^{w}$ is the wholesale price; $\lambda \in[0,1]$ is the retailer's bargaining power.
} 
In contrast, Schlippenbach and Teichmann (2012) build a theory model showing how retailers can require private quality standards to increase their buyer power: farmers incur costs in order to provide the demanded higher quality, so that they cannot sell to low-quality rivals without a loss 15 This shows that it is a priori not clear how Fairtrade labels affect the profit sharing along the value chain.

Several studies track the Fairtrade premium along parts of the value chain and find that Fairtrade coffee is more expensive at all stages. However, the price premium for the farmer is the system's core argument, but Gingrich and King (2012) claim that the Fairtrade label increases the retailing price of a product by more than this farmer price premium. If this is true, which stage of the value chain receives the benefit of Fairtrade certification? The answer depends in practice on the participants' market power and bargaining.

Using data from coffee cooperatives in Ethiopia, Minten et al. (2018) find that about a third of the price premium at the export level, i.e. at the border of the producing country, is transmitted to farmers 16

Using a broader approach, Johannessen and Wilhite (2010) include the roaster and retailer into the picture and find that about $70 \%$ of the retail price paid for Fairtradecertified coffee in Norway remains in the consumer country. ${ }^{17}$ Similar to the present study, Valkila et al. (2010) ask how much consumers pay more for Fairtrade-certified coffee and how this price premium trickles down through the value chain. They find that $48 \%$ $(€ 2.30 / \mathrm{kg})$ of the retail price of conventional coffee goes to the producer country (farmers, cooperatives, and exporters confounded) and only $35 \%(€ 2.60 / \mathrm{kg})$ for Fairtrade-certified coffee: while the overall amount is larger, the proportion is smaller for Fairtrade-certified coffee. The authors conclude that the price premium paid by the consumer benefits mainly the roasters.

The empirical studies concentrate on the distribution of the coffee price along the value chain, while the present study focuses on the difference between this distribution for conventional and Fairtrade-certified coffee.

\footnotetext{
15 Schlippenbach and Teichmann $(2012)$ use a similar Nash bargaining solution, but set the bargaining parameter $\lambda$ to 0.5 , so that the profit sharing depends only on deviation payoffs.

16 Minten et al. (2018) do not distinguish between organic certification and Fairtrade. The average price premium for certification at the farmer level is $5 c$ per lb of green coffee, while it is $15 c$ at the export level.

${ }^{17}$ The quoted number refers to the retail example, not the catering sale of brewed coffee. The detailed shares are: $13.8 \%$ for the retailer, $2.4 \%$ for the certifying body, $58.2 \%$ for the roaster; $12.5 \%$ goes to the cooperative and $13.1 \%$ to the farmer.
} 


\section{Data and descriptive trends}

\subsection{Data sources}

This study brings together sources on the crucial steps of a typical coffee value chain: farmer cooperatives, roasters, and retailers.

For the farmers, I use the market price for Arabica coffee which is given by the "C" coffee futures from the New York Stock Exchange ${ }^{18}$ To determine the Fairtrade price for each period, I combine stock market prices and Fairtrade rules on the floor price and social premium, as shown in Fig. 1. Empirical research repeatedly shows that effective transaction prices for conventional coffee are indeed close to the stock market prices and transaction prices for Fairtrade-certified coffee are close to the regulated Fairtrade price (e.g. Janvry et al. 2015, Valkila et al. 2010). These commodity prices do not apply for specialty coffee, which sells at higher prices. This study cannot account for such heterogeneity, but evidence suggests it is a marginal phenomenon for coffee sold in US supermarkets ${ }^{19}$ Industry wisdom as quoted in Bettendorf and Verboven (2000) and Valkila et al. (2010) says 1.19lb of green coffee beans transforms into 1lb of roasted coffee, as roasting evaporates water out of the beans.

For the roasters, the price for green beans is one of the main input costs. Additionally, roasters pay FLO-Cert a license fee of 10 c per lb of Fairtrade-certified coffee ${ }^{20}$ The PriceTrak dataset from National Promotion Reports LLC. (2016) provides wholesale prices, i.e. the manufacturer's revenue per unit, for roasted coffee in 57 local US markets for the years 2001 to 2012212 This data provides daily information about regular list prices and wholesale promotions at the Universal Product Code (UPC) level for each of the covered markets. An important limitation of the data is that only about half of US supermarket chains buy from wholesalers (Nakamura and Zerom 2010), while the biggest retailers make direct and probably more advantageous contracts with roasting companies. My results based on this data are thus only valid for intermediate-size retailers.

\footnotetext{
${ }^{18}$ Throughout this study, I use prices for Arabica coffee. Virtually all coffee is composed of either Arabica, Robusta, or a mix of both; but I do not observed the composition of the products. Robusta and Arabica stock market prices are highly correlated. "C" futures on the New York Stock Exchange (NYSE) are the reference price for Arabica; London stock exchange gives the reference for Robusta. I use the "C" price as quoted on www.investing.com/commodities/us-coffee-c-historical-data, consulted on October 1, 2018.

${ }^{19}$ The Fairtrade/direct trade website "Transparent Coffee" compiles data on hundreds of Fairtrade contracts and finds $87 \%$ use the "C" price www.transparenttradecoffee.org/insights/fair-trade-proofcoffee-contracts-2010-to-2014, consulted on October 1, 2018. Moreover, open-ended, semi-structured interviews with large trading firms in Bogotá, Columbia, in July 2016 confirm the assumption that contracts are indexed on stock market prices, plus constant country- and certification-specific premiums.

${ }^{20}$ Fair Trade USA, private communication. Since 2012, Fair Trade USA has changed the rules such that small roasters (below 20,000lbs of coffee per year) pay no fee, while larger roasters pay a fee between $5 \mathrm{c}$ and $8.5 \mathrm{c}$ per lb, depending on the share of Fairtrade-certified coffee in their business.

${ }^{21}$ The wholesale data used in this study is a longer version of the data used in Nakamura and Zerom (2010), when National Promotion Reports was called PromoData.
} 
For the retailer, these wholesale prices are the main input cost. For consumer prices and sales, i.e. the retailer's revenue, I use the research data set provided by Information Resources Inc. (2015) on grocery supermarkets and drug stores in 50 local US markets for the years 2001 to 2012. This dataset is described in great detail by Bronnenberg et al. (2008) and contains UPC-week-level coffee sales for each supermarket in the IRI panel. Protecting sensitive business data, IRI anonymizes retail chains, so I cannot use information on private labels.

Fair Trade USA provided a UPC-level list of Fairtrade-certified products with the date they first received the certification. This data is matched to the wholesale and retail price data.

Beyond this coffee specific data, I use data on taxes from the Tax Foundation ${ }^{22}$ there is no federal coffee import tax in the US, but retail coffee sales are subject to the statespecific grocery taxes. The grocery tax rates varies between $0 \%$ (for 35 of the 50 IRI markets) and 5.5\% (Knoxville, Tennessee).

Given my research question and the similarity of the Fairtrade and conventional value chains, additional data on costs is not necessary: for the sake of this study, we are interested in the difference between Fairtrade-certified and conventional profit sharing and it seems safe to assume that transportation costs within the US, transportation costs to the US ${ }^{23}$ packaging costs, roasting costs, and the opportunity cost of shelf-space are identical for Fairtrade-certified and conventional coffee.

\section{$2.2 \quad$ Data limitations}

An important, but difficult, question is how much farmers pay for certification. On the FLO-Cert website, one finds extensive documentation (e.g. FLO-Cert GmbH 2015) showing that license fees depend on the level of the cooperative ${ }^{24}$ and the number of members; for example, a first degree coffee cooperative with fewer than 50 members (cheapest category) pays $€ 1,500$ initially and then $€ 1,200$ annually. Importantly, these payments are not dependent on quantities produced or sold. Using a simple theory model, Janvry et al. (2015) make the strong claim that, in equilibrium, all of the Fairtrade benefits go toward the payment of the farmer license fees. Using survey data, Janvry et al. (2015) find that certification costs the cooperatives on average $3 c$ per lb produced, while Valkila et al. (2010) find 5.5c per lb exported; this number likely varies greatly with cooperative size. Thus, this study refrains from calculating the share of the Fairtrade premium going to the labeling organization.

\footnotetext{
${ }^{22}$ https://taxfoundation.org/state-sales-gasoline-cigarette-and-alcohol-tax-rates/; consulted on February 1, 2017.

23 Valkila et al. (2010) use an estimate of $7 \dot{c}$ per $\mathrm{kg}$ of green coffee.

${ }^{24}$ First degree cooperatives' members are farmers directly, a second degree cooperative is a "cooperative of cooperatives."
} 
This study cannot describe the profit sharing between cooperative and farmer. Both the payment of the license fee and the investment of the social premium are managed at cooperative level. Valkila et al. (2010) show that the cooperative retains $28 \mathrm{c}$ per lb of green coffee. Technically, the cooperative belongs to its members, so that in the Fairtrade literature, cooperatives and farmers are often seen as one single actor. However, the literature repeatedly shows that farmers see the cooperative as one potential buyer amongst many and they sell to the one offering highest prices (e.g. Valkila and Nygren 2010). Moreover, Johannessen and Wilhite (2010) show that the higher level cooperative (a cooperative whose members are cooperatives) in their data invests the Fairtrade premium in order to improve its management and farmers are not even aware of the Fairtrade certification; the lower level cooperative (a cooperative whose members are farmers) on the contrary pays out much of the Fairtrade premium to the farmers, who are thus well aware of Fairtrade benefits.

\subsection{Data selection}

The main data set contains only the products and markets for which I have both wholesale and retail prices. The two data sets have different geographical coverage. The IRI retail data contains 50 regional markets, but only 38 of them could be matched to the PriceTrak wholesale data. For comparability, I only keep ground coffee, dropping UPCs that refer to instant coffee, whole beans and single-serve coffee pods. As we are interested in the comparison of Fairtrade and conventional products, I further drop the states for which no Fairtrade products could be matched, reducing the number of regional markets to 21 .

For the year 2012, for example, matching dramatically reduces the number of different products by $90 \%$ (from 3,037 to 284 UPCs), but these matched UPCs have a cumulated market share of $37 \%$. This means that popular products with high market shares are overrepresented in the resulting data set. Table 6 in the Appendix gives a further overview of the selection arising from keeping only matched observations. The matched products are slightly cheaper ( $\$ 0.43$ difference): this confirms that the matching keeps the cheap mainstream products and drops more expensive small brands. The matched products have slightly larger package sizes (1.7 ounce difference) and are more often decaffeinated (18\% vs. 16\%). The share of Fairtrade-certified products is similar with $3.15 \%$ in the matched sample and $3.12 \%$ in the remaining IRI observations. All of these differences are statistically significant, due to the large sample size, but their magnitude seems reasonably small.

The data is available from 2001 to 2012, but only very few products are Fairtradecertified in the early years. For a long time, Fairtrade-certified coffee was sold in specialized "world shops" which might explain why I have no Fairtrade-certified observations 


\begin{tabular}{lccccc}
\hline \hline & Mean & SD & Minimum & Median & Maximum \\
\hline Package size (in oz.) & 16.2 & 9.1 & 5.3 & 11.3 & 39.0 \\
Package size (in g) & 459 & 258 & 150 & 320 & 1106 \\
Retail price per unit & $\$ 6.70$ & $\$ 2.92$ & $\$ 1.20$ & $\$ 5.99$ & $\$ 27.46$ \\
Retail price per lb & $\$ 7.26$ & $\$ 2.45$ & $\$ 1.59$ & $\$ 6.94$ & $\$ 30.70$ \\
Wholesale price per unit & $\$ 5.48$ & $\$ 2.66$ & $\$ 0.87$ & $\$ 4.34$ & $\$ 14.82$ \\
Wholesale price per lb & $\$ 5.74$ & $\$ 1.54$ & $\$ 1.16$ & $\$ 5.42$ & $\$ 14.80$ \\
Farmer price per unit & $\$ 2.42$ & $\$ 1.48$ & $\$ 0.54$ & $\$ 1.84$ & $\$ 8.02$ \\
Farmer price per lb & $\$ 2.40$ & $\$ 0.54$ & $\$ 1.52$ & $\$ 2.24$ & $\$ 4.16$ \\
Grocery tax per lb & $\$ 0.01$ & $\$ 0.04$ & $\$ 0.00$ & $\$ 0.00$ & $\$ 0.60$ \\
Fairtrade-certified & $5.35 \%$ & 0.23 & 0 & & 1 \\
Organic & $0.36 \%$ & 0.06 & 0 & & 1 \\
Decaffeinated & $19.32 \%$ & 0.40 & 0 & & 1 \\
\hline Observations & $1,874,732$ & & & & \\
\hline \hline
\end{tabular}

Table 1: Descriptive overview of main data set Source: main data set with observations at UPC-week-store level, own computations.

until 2009 in the matched sample. In 2009, only two UPCs are Fairtrade-certified, so I restrict the analysis to the most recent years from 2010 to 2012. Even in this restricted data set, the Fairtrade market share rises quickly and most Fairtrade-certified sales occur in 2012 .

\subsection{Descriptive statistics}

The resulting main data set for the years 2010 to 2012 contains close to 2 million weekstore-UPC-level observations from 21 markets (in 13 US states) and 775 stores. There are 340 distinct UPC-level products from 55 brands, produced by 23 parent companies. The coffee market is highly concentrated, with the three largest parent companies (J.M. Smucker Company, Kraft Foods, and Massimo Zanetti USA) covering a market share of over $80 \%$. Only five companies offer Fairtrade-certified coffee.

Table 1 provides a descriptive overview of the UPC-week-store-level main data set. Package size varies widely, between $150 \mathrm{~g}$ and $1100 \mathrm{~g}$ with an average of $459 \mathrm{~g}$. The data contains prices on three steps of the value chain: at the farmer level, the price is on average $\$ 2.42$ per $\mathrm{lb}$, at wholesale level it is $\$ 5.74$ per $\mathrm{lb}$, and for the retail consumer it is $\$ 7.26$ per lb. In the final data, $5.35 \%$ of the observations are Fairtrade-certified, while only $0.36 \%$ are organic. Decaffeinated coffee makes up $19.3 \%$ of the observations. The grocery tax is so small that most of the following analysis does not explicitly refer to it.

\subsection{Rise of single-serve coffee}

An important phenomenon that appeared in parallel to the rise of the Fairtrade are single-serve coffee pods like Nespresso and Keurig K-Cups. Nespresso does not appear 
in the data, as they are sold in specialized Nespresso stores, while K-Cups are sold by all major retail chains. Keurig developed its home brewer in 2004 and business took off with the acquisition of Green Mountain Coffee in 2006. In 2012, the original patent on the pod shape expired, meaning that other firms can now sell Keurig-brewer compatible pods. K-Cups are typically sold in packs of 6,12 , or 24 pods, but one pod contains only about $10 \mathrm{~g}$ of coffee; overall package size is thus small.

Figure 2 shows the market share and price level for single-serve and Fairtrade-certified coffee. As we see in Figure 2a, the market share of single-serve coffee stagnates for a long time, before the introduction of single-serve cup brewers, that is when single-serve coffee came as "coffee bags", similar to tea bags. With the appearance of coffee pods by Keurig, the single-serve market increases dramatically reaching a market share of over $20 \%$ of sold units in 2012. End of 2012, Keurig is the largest roaster of Fairtrade-certified coffee in terms of value and in terms of units (but not in volume): the market share of Fairtrade K-Cups at the end of 2012 is roughly equal to the market share of ground Fairtrade coffee.

Figure 2b shows that single-serve pods are more expensive when we look at prices per pound of coffee, reaching prices of around $\$ 30$ per lb, whereas ground coffee sells on average at $\$ 7.30$ per lb. The price of green beans constitutes only a tiny share of this price, and Fairtrade-certified pods sell roughly at the same prices as - if not cheaper than conventional pods. On the contrary, Fairtrade-certified ground coffee sells at significantly higher prices than conventional ground coffee.

In order to ensure comparability of the products in the data set, I exclude single-serve pods from the following analysis. It is a puzzle why Fairtrade certification seems to yield no price premium in the coffee pod market.

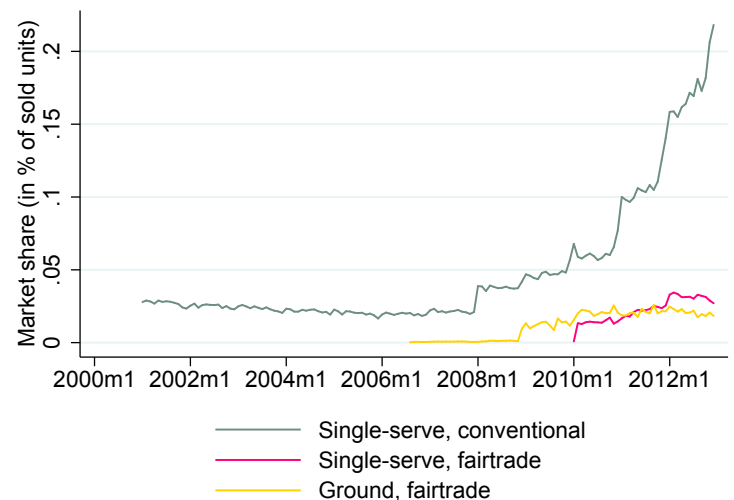

(a) Market share (percentage of sold units, remaining share is ground conventional)

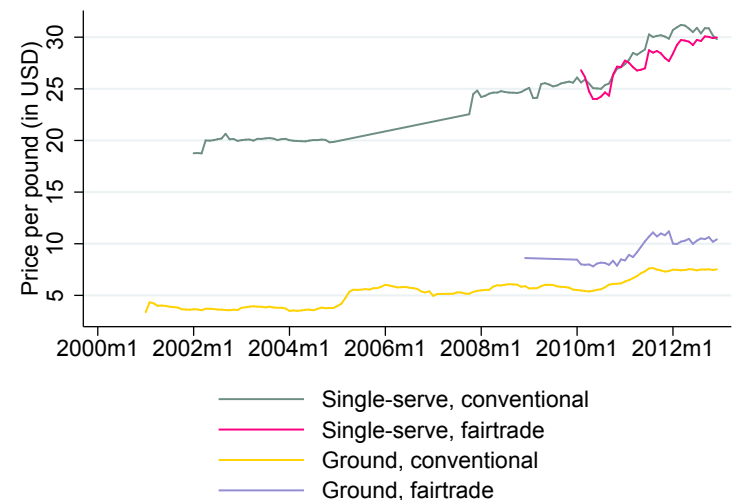

(b) Average retail prices per lb (weighted by sales)

Figure 2: Trends on the coffee market 


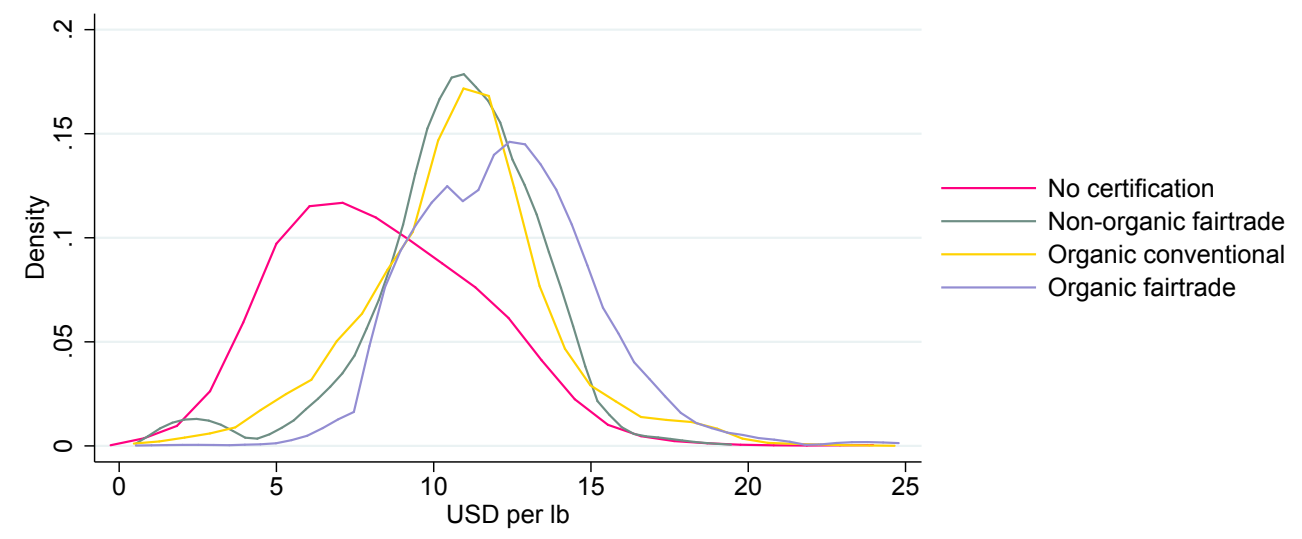

Figure 3: Distribution of retail prices in 2012

Kernel density using Stata's kdensity, bandwith=0.45; pairwise Kolmogorov-Smirnov test for equality of distribution functions finds that all four distributions are significantly different from each other with $p<0.001$. Source: main data set, own computations.

\subsection{Fairtrade and organic certification}

Fairtrade-certified coffee does not appear in the IRI retail data until 2008. The market share then quickly increases, reaching $3 \%$ (of value and of units purchased, among ground coffee) in 2011 and $2.5 \%$ in $2012 .{ }^{25}$ These numbers exclude the single-cup pods, which are often Fairtrade-certified. Unfortunately, IRI data is not available for more recent years.

\begin{tabular}{lccc}
\hline \hline & Not organic & Organic & Total \\
\hline Conventional & $1,774,233$ & 181 & $1,774,414$ \\
& $(94.64 \%)$ & $(0.01 \%)$ & $(94.65 \%)$ \\
Fairtrade & 93,668 & 6,650 & 100,318 \\
& $(5.00 \%)$ & $(0.35 \%)$ & $(5.35 \%)$ \\
\hline Total & $1,867,901$ & 6,831 & $1,874,732$ \\
& $(99.64 \%)$ & $(0.36 \%)$ & $(100.00 \%)$ \\
\hline \hline
\end{tabular}

Table 2: Frequencies of certification: comparison and overlap of Fairtrade and organic Source: main data set with observations at UPC-week-store level, own computations.

In addition to Fairtrade certification, coffee is often also certified as organic. Table 2 shows the number of certified products at UPC-week-store-level. We see that organic certification is marginal compared to Fairtrade certification. There is substantial overlap in certification: Fairtrade-certified coffee is much more likely to carry organic certification than conventional coffee.

Figure 3 shows the retail price distribution for ground coffee with and without certification. We see that non-certified coffee is cheapest. Certified coffee is more expensive: Fairtrade-certified and organic have about the same price distribution, while the price

\footnotetext{
${ }^{25}$ This market share is smaller than the $5.35 \%$ in Table 1 , because it is weighted by sales and Fairtradecertified coffee is bought relatively little compared to its availability in stores.
} 


\begin{tabular}{lcccc}
\hline \hline & Conventional & Fairtrade & Difference & \\
\hline Retail price per unit & $\$ 6.71$ & $\$ 6.56$ & $-\$ 0.15$ & $* * *$ \\
Retail price per lb & $\$ 7.10$ & $\$ 10.02$ & $\$ 2.91$ & $* * *$ \\
Wholesale price per unit & $\$ 5.47$ & $\$ 5.61$ & $\$ 0.13$ & $* * *$ \\
Wholesale price per lb & $\$ 5.58$ & $\$ 8.59$ & $\$ 3.02$ & $* * *$ \\
Farm gate price per unit & $\$ 2.45$ & $\$ 1.83$ & $-\$ 0.63$ & $* * *$ \\
Farm gate price per lb & $\$ 2.38$ & $\$ 2.80$ & $\$ 0.42$ & $* * *$ \\
\hline Observations & $1,774,414$ & 100,318 & & \\
\hline \hline
\end{tabular}

Two-sided Welch t-test, unequal variances. Stars denote significance: $* * *$ means $p<0.01$.

Table 3: Comparison of Fairtrade and conventional coffee prices along the value chain and significance of the price difference (t-test)

Source: main data set with observations at UPC-week-store level, own computations.

for coffee with both Fairtrade and organic certification is slightly higher. This study concentrates on the price premium for Fairtrade-certified coffee over conventional: Table 3 shows the price premium for Fairtrade certification over conventional (both organic and non-organic) along the value chain. The difference in prices is significant (two-sided t-test) at all levels of the value chain. The retail and farmer prices per unit are smaller for Fairtrade-certified coffee, as the package size is typically smaller than for conventional coffee.

The popularity of Fairtrade-certified coffee shows geographical disparities. We see on Figure 4a that coastal states have more interest for Fairtrade, as shown by the Google search frequency for "Fairtrade". Consistently, the states along the coasts also have higher market shares of Fairtrade-certified coffee in the IRI data, as shown on Figure 4b.

\subsection{Generally low transmission of bean prices}

Several previous studies Nakamura and Zerom 2010, Bettendorf and Verboven 2000, Feuerstein 2002) ask how commodity price volatility trickles down to consumers. They typically find that consumer prices do not move on a one-to-one level with farmer prices.

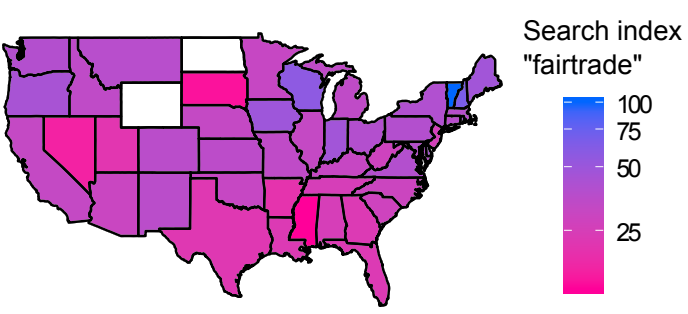

(a) Google searches for "Fairtrade" (index $=100$ for Vermont with the most searches)

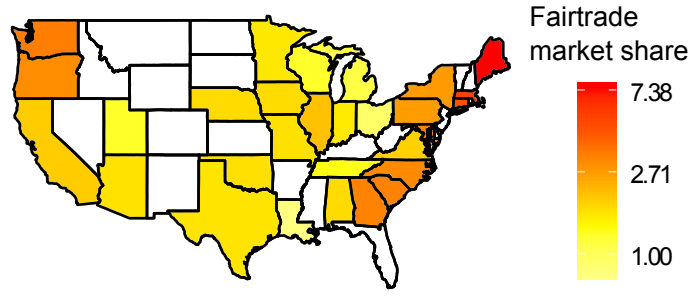

(b) Market share (in value) of Fairtrade

Figure 4: Geographical disparities in 2012 Source: main data set and www.google.com/trends/ own computations. 


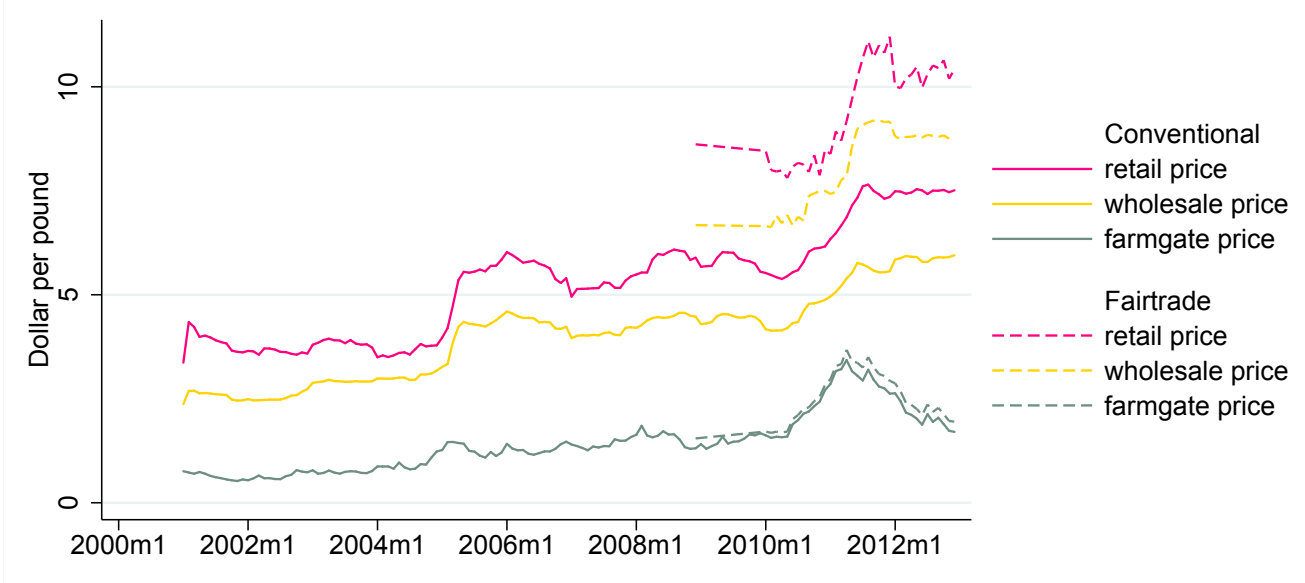

Figure 5: Price evolution at retail, wholesale and farmer level Solid lines show conventional coffee, dashed lines show Fairtrade-certified coffee. Source: main data set, own computations.

Figure 5 confirms this finding in my data: while wholesale prices and retail prices move in parallel, farmer prices only loosely correlate with wholesale and retail prices. For example, a graphical analysis suggests that the price surge of green coffee prices in 2011 was transmitted into wholesale prices, while the subsequent decrease in green coffee price in 2012 did not lead to lower wholesale and retail prices. This pattern appears consistent with asymmetric cost pass-through, as in Bonnet and Villas-Boas (2016). The correlation between retail prices and wholesale prices is 0.77 , but between retail and farmer prices it is only 0.13 .

\section{How much do consumers pay extra for Fairtrade?}

Ideally, we would like to consider products that switch from conventional to Fairtradecertified: comparing prices before and after the switch would allow us to identify the price premium of Fairtrade certification for otherwise identical products. Unfortunately, in my data set, only one UPC-level product switches in this way. Generally, coffee brands prefer introducing new products with certification, rather than adding the Fairtrade label to existing products. Given this data issue, I choose two control strategies: I first use hedonic price regressions, controlling for brand fixed effects and all observable characteristics. Then, I compare the products from those brands only that sell both Fairtrade-certified and conventional coffee.

Following Lancaster (1966), a product can be modeled as a bundle of characteristics and its price is then the sum of the prices of each characteristic. The value of each characteristic can then be computed with a hedonic pricing approach, as in Minten et al. (2018), where we regress the price of a good on a vector of its characteristics.

Table 4 shows the result of a linear regression of prices on product characteristics, as well as market, week, and company fixed effects. Column (1) displays the coefficients 


\begin{tabular}{lccc}
\hline \hline & \multicolumn{3}{c}{ Retail price per lb } \\
\cline { 2 - 4 } & $(1)$ & $(2)$ & $(3)$ \\
\hline Fairtrade-certified & $2.03^{* * *}$ & $1.84^{* * *}$ & $1.20^{* * *}$ \\
& $(0.007)$ & $(0.007)$ & $(0.015)$ \\
Decaffeinated & & $0.19^{* * *}$ & $0.35^{* * *}$ \\
& & $(0.004)$ & $(0.003)$ \\
Organic & & $2.85^{* * *}$ & $0.85^{* * *}$ \\
& & $(0.025)$ & $(0.027)$ \\
Vol (lb) & $-4.31^{* * *}$ & $-4.38^{* * *}$ & $-4.61^{* * *}$ \\
& $(0.026)$ & $(0.026)$ & $(0.026)$ \\
Vol (lb) squared & $0.86^{* * *}$ & $0.89^{* * *}$ & $1.04^{* * *}$ \\
& $(0.010)$ & $(0.010)$ & $(0.009)$ \\
Constant & $8.45^{* * *}$ & $8.43^{* * *}$ & $8.89^{* * *}$ \\
& $(0.040)$ & $(0.040)$ & $(0.144)$ \\
\hline Market FE & Yes & Yes & Yes \\
Week FE & Yes & Yes & Yes \\
Company FE & No & No & Yes \\
\hline N & \multicolumn{3}{c}{$1,874,732($ all columns) } \\
R2 & 0.34 & 0.35 & 0.46 \\
\hline \hline Standard errors in parenthesis, $* * *$ means $p<0.01$. &
\end{tabular}

Table 4: Hedonic linear price regression for retail prices (in USD per lb) Source: main data set with observations at UPC-week-store level, own computations.

for the most simple specification, using no company fixed effects and controlling only for package volume. In this specification, Fairtrade-certified coffee is $\$ 2.03$ per lb more expensive than conventional coffee. Column (2) adds dummies for organic certification and decaffeination, which reduces the estimate for the value of Fairtrade certification to $\$ 1.84$ per lb. Column (3) controls for brand image by adding company fixed effects. This further reduces the estimate for the value of Fairtrade certification to $\$ 1.20$ per lb. Comparing annual mean prices, Valkila et al. (2010) find a very similar estimate of around $\$ 1.60$ per $1 b^{26}$ for Finnish retail markets between 2006 and 2009.

\section{Where does the extra dollar go?}

I then estimate the Fairtrade price premium at the other two stages of the value chain. Table 5 shows the results for wholesale prices (column 1 to 3 ) and farmer prices (column 4). I first regress wholesale prices on product characteristics and then add further fixed effects. Controlling for characteristics and brand fixed effects reduces the estimate of the price premium for Fairtrade, but it is always higher than the corresponding estimate for retail prices in Table 4. Column (3) gives the main estimate for the Fairtrade price

\footnotetext{
${ }^{26}$ Converted from $2.80 € / \mathrm{kg}$ using the exchange rate quoted in Valkila et al. (2010).
} 


\begin{tabular}{|c|c|c|c|c|}
\hline & \multicolumn{3}{|c|}{ Wholesale price per lb } & \multirow{2}{*}{$\frac{\text { Farmer price }}{(4)}$} \\
\hline & $(1)$ & $(2)$ & $(3)$ & \\
\hline \multirow[t]{2}{*}{ Fairtrade-certified } & $2.54^{* * *}$ & $2.45^{* * *}$ & $1.44^{* * *}$ & $0.21^{* * *}$ \\
\hline & $(0.004)$ & $(0.004)$ & $(0.008)$ & $(0.000)$ \\
\hline \multirow[t]{2}{*}{ Decaffeinated } & & $0.04^{* * *}$ & $0.17^{* * *}$ & \\
\hline & & $(0.002)$ & $(0.002)$ & \\
\hline \multirow[t]{2}{*}{ Organic } & & $1.42^{* * *}$ & $0.51^{* * *}$ & $0.37^{* * *}$ \\
\hline & & $(0.014)$ & $(0.014)$ & $(0.000)$ \\
\hline \multirow[t]{2}{*}{ Vol (lb) } & $-2.45^{* * *}$ & $-2.45^{* * *}$ & $-1.82^{* * *}$ & \\
\hline & $(0.015)$ & $(0.015)$ & $(0.014)$ & \\
\hline \multirow[t]{2}{*}{ Vol (lb) squared } & $0.57^{* * *}$ & $0.58^{* * *}$ & $0.40^{* * *}$ & \\
\hline & $(0.006)$ & $(0.006)$ & $(0.005)$ & \\
\hline \multirow[t]{2}{*}{ Constant } & $5.62^{* * *}$ & $5.60^{* * *}$ & $5.15^{* * *}$ & $1.73^{* * *}$ \\
\hline & $(0.023)$ & $(0.023)$ & $(0.077)$ & $(0.000)$ \\
\hline Market FE & Yes & Yes & Yes & No \\
\hline Week FE & Yes & Yes & Yes & Yes \\
\hline Company FE & No & No & Yes & No \\
\hline $\mathrm{N}$ & \multicolumn{4}{|c|}{$1,874,732$ (all columns) } \\
\hline $\mathrm{R} 2$ & 0.44 & 0.44 & 0.61 & 0.99 \\
\hline
\end{tabular}

Standard errors in parenthesis, *** means $p<0.01$.

Table 5: Hedonic linear price regression for wholesale and farmer prices (in USD per lb) Source: main data set with observations at UPC-week-store level, own computations.

premium at wholesale level and states that roasters receive $\$ 1.44$ per lb more for Fairtradecertified coffee, compared to conventional coffee.

The farmer price is independent of the final package size and decaffeination, as these are product characteristics that arise only after the coffee has reached the manufacturer; using stock market prices, there is no geographical or between-brand variation in farmer prices and, thus, no need for market and company fixed effects. The price premium at the farmer level is lower than at the other stages of the value chain, with an estimate around 23c per lb (Table 5 , column (4)).

When analyzing profit-sharing along the value chain, one often has to confront the problem that each agent has some fixed and marginal costs that are unknown to the researcher. In coffee roasting for example, the cost share of green bean input is estimated around a considerable $60 \%$ of total cost, leaving around $40 \%$ for roasting and packaging expenses (Bettendorf and Verboven 2000). However, this problem does not arise here, because this study examines the difference of margins between two almost identical value chains: indeed, there is no reason that the cost for transporting, roasting, and packaging Fairtrade-certified coffee is any different than the conventional cost for the manufacturer. The opportunity cost of shelf-space for the retailer is also unlikely to differ between the two types of coffee. The only additional costs in the Fairtrade value chain are due to licensing: for the roaster, there is the Fairtrade license fee of $10 c$ per lb until January 
1, 2012. For the retailer, there is no license fee. For the farmer, the license fee is a fixed annual amount, independent of the amount of coffee sold, thus varying with sales variations. Differences in the Fairtrade premium beyond this license payments at different stages of the value chain must be caused by adjustments of absolute profit margins.

Consumers pay $\$ 1.20$ per lb more for Fairtrade-certified coffee (Table 4 , column (3)), while the price premium is $\$ 1.44$ per lb at the manufacturer's wholesale prices and $21 c$ per lb at the cooperative's farmer prices (Table 5, column (3) and (4)). As the differences in price premiums are not driven by marginal cost, they reflect changes in profit margins. Thus, retailers make (1.20-1.44=) 24c less profit per lb of Fairtrade-certified coffee, compared to conventional coffee, while manufacturers make (1.44-0.21-0.10=) $\$ 1.13$ more 27

Taking an alternative, more graphical, approach, I compare prices keeping only the four companies that produce both Fairtrade-certified and conventional coffee, assuming that their brand value and (perceived) quality should be more homogeneous than the entire sample 28 These four companies cover only $3 \%$ of the market. Table 7 in the Appendix shows that their products are significantly different in all of the observable characteristics compared to other companies' products: products from these four companies are, on average, $82 \mathrm{c}$ more expensive and significantly smaller (11.4 oz vs. $16.4 \mathrm{oz}$ for other companies). Consequently, their price level per pound is significantly higher than the other companies on the market ( $\$ 10.53$ vs. $\$ 7.08$ per lb), placing these brands in a premium segment of the coffee market. They are significantly more often certified organic and less often decaffeinated.

Figure 6 shows the retail price per pound for those companies that offer both Fairtradecertified and conventional coffee in 2012.29 On the left-hand side, Figure 6a shows that the price for Fairtrade-certified coffee is, on average, $\$ 1.10$ per lb higher $(\$ 10.27$ per $\mathrm{lb}$ vs. $\$ 9.17$ per $\mathrm{lb}$ ) and shows the decomposition along the value chain to the farmer, retailer, and manufacturer with the coffee importing trader. The trader's share is not distinguishable in my data from the manufacturer, so the two are combined. On the right-hand side, Figure 6b shows only the difference between the Fairtrade-certified and conventional at each stage of the value chain. Similar to the analysis on the regression results, we see that farmers receive an average of $24 \mathrm{c}$ per $1 \mathrm{~b}$ more for Fairtrade-certified coffee, manufacturers receive $\$ 1.16$ per lb more and retailers reduce their margins by $27 c$ per lb. I do not deduce the additional FLO roaster fee here, because the FLO set it to

\footnotetext{
${ }^{27}$ The $10 \mathrm{c}$ are the FLO license fee for roasters before 2012.

${ }^{28}$ Actually, the largest coffee roaster in my sample, the J.M. Smucker Company (owner of the Folger's coffee brand), held a small brand called Millstone that sold some Fairtrade-certified coffee. I exclude Smucker from the list of Fairtrade-certified roasters, because Millstone constitutes only .03\% of Smucker's sales and Fairtrade-certified coffee $.0068 \%$.

${ }^{29}$ Such a graphical analysis does not control for time variation. As most of the Fairtrade sales are concentrated in 2012 in my data, a comparison of Fairtrade-certified versus conventional over the entire three years gives a biased estimate. Table 8 in the Appendix gives the regression results for these companies analogously to Table 4 and 5 .
} 
zero for many roasters since the beginning of 2012 .

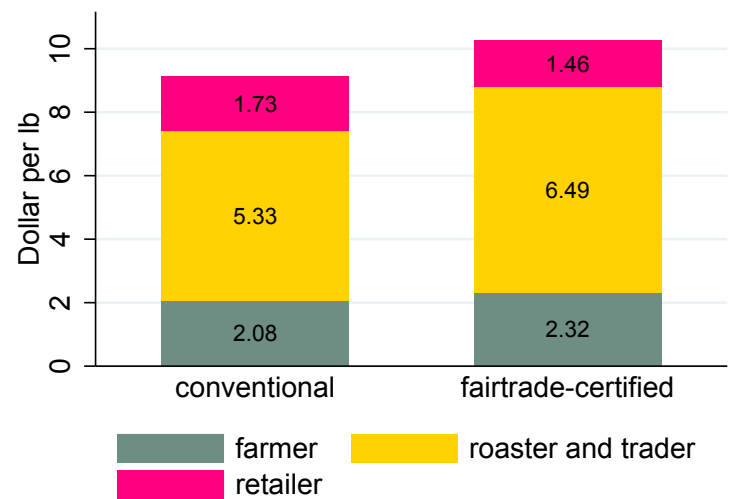

(a) Comparison Fairtrade-certified and conventional

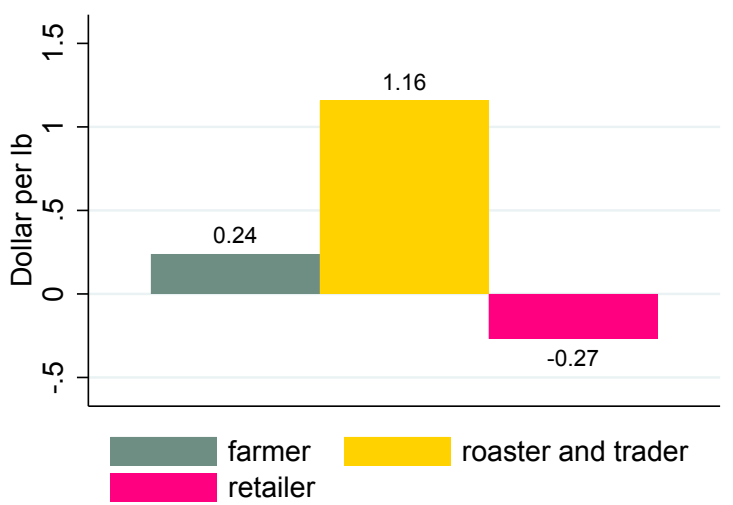

(b) Difference Fairtrade-certified minus conventional

Figure 6: Decomposition of the retail price (in USD per lb) for Fairtrade-certified and conventional coffee.

Source: main data only for 2012, keeping only the four companies selling Fairtrade-certified coffee, grocery tax deducted and not shown; own computations.

These two complementary approaches come to roughly to the same distribution of the Fairtrade premium along the value chain 30 I find that the generally positive and large price premium for Fairtrade certification is distributed strongly unevenly along the participants: the largest portion goes to the manufacturers ${ }^{31}$ while the retailers even reduce their profit margins despite the premium paid by the consumer.

Why is the value added shared differently between retailers and manufacturers? The standard model of industrial organizations literature follows the line of Draganska et al. (2010), explained in Section 1.5. This model offers two explanations: one explanation is increased bargaining power, but this typically applies to all products of a given manufacturer, so it does not explain the full Fairtrade-premium observed here within the products of a given manufacturer; the other explanation is market power, as resulting from the outside option of the negotiating partners: if the retailer does not offer a given product, how much will this affect overall profits? Very few manufacturers produce Fairtrade-certified coffee, Fairtrade buyers probably have lower price elasticity, and offering Fairtrade-certified products positively affects the general image of the supermarket. These elements are consistent with the retailer having less market power, i.e. lower deviation payoffs, for Fairtrade-certified products than for conventional coffee, which in turn explains the observed reduction of the retailer's profit margin to the benefit of the

\footnotetext{
${ }^{30}$ Additionally, the Appendix states the entire regression analysis for the four companies that produce both Fairtrade-certified and conventional coffee.

${ }^{31}$ Manufacturers and traders, actually, but the traders are unlikely to have large market power in this market: just like the farmers, they probably suffer from the immense over-supply of Fairtrade-certified coffee.
} 
manufacturer.

\section{Conclusion}

This study asks how much the consumer pays extra for Fairtrade certification on coffee in US supermarkets and how this premium is distributed among the participants of the coffee value chain. The estimates for the price premium range between 70c per lb and $\$ 2$ per lb, depending on the control strategy, with most estimates around $\$ 1$ per lb.

Of this premium, the largest portion goes to the manufacturer who creates the brand value. The estimates show that retailers make less profit on Fairtrade-certified coffee than on conventional, suggesting that the certification provides market power to the manufacturer, relative to the retailer. As the number Fairtrade-certified manufacturers is small and offering Fairtrade-certified products may have a positive externality on the reputation of the retailer, it appears realistic that the retailers have relatively small market power in the negotiations of wholesale prices for Fairtrade-certified coffee.

The farmer portion of this premium is between a fifth and a quarter of the total premium. Previous research (e.g. Gingrich and King 2012) suggests measuring the "efficiency" of the Fairtrade system: if a Fairtrade-certified product is seen as a product bundled with a donation, one might compute how efficient this transfers money from the consumer to the farmer. Taking my regression results, the consumer would have to spend an additional $(1.20 / .21=) \$ 5.71$ in order to transfer $\$ 1$ to the farmer, which is roughly in line with the estimates of Gingrich and King (2012). However, in the light of evidence of Janvry et al. (2015), these estimates probably over-estimate the benefit to the farmer, as they do not take into account the license fees paid by farmer cooperatives to participate in the Fairtrade system. These license fees are likely to erode some, if not all, of the financial transfer from the consumer to the farmer. Given the distribution of market power along the value chain, it is somewhat surprising that the Fair Trade USA decided in 2011 to abolish license fees for roasters, but not for farmers. 


\section{References}

Akiyama T and Varangis P (1990) The impact of the International Coffee Agreement on producing countries. The World Bank Economic Review, 4(2): 157-173.

Andreoni J (1989) Giving with impure altruism: applications to charity and Ricardian equivalence. Journal of Political Economy, 97(6): 1447-1458.

Basu A and Hicks R (2008) Label performance and the willingness to pay for Fair Trade coffee: a cross-national perspective. International Journal of Consumer Studies, 32(5): 470-478.

Bettendorf L and Verboven F (2000) Incomplete transmission of coffee bean prices: evidence from the Netherlands. European Review of Agricultural Economics, 27(1): 1-16.

Beuchelt T and Zeller M (2011) Profits and poverty: certification's troubled link for Nicaragua's organic and fairtrade coffee producers. Ecological Economics, 70(7): 13161324 .

Bonnet C and Bouamra-Mechemache Z (2016) Organic label, bargaining power, and profit-sharing in the French fluid milk market. American Journal of Agricultural Economics, 98(1): 113-133.

Bonnet C and Villas-Boas S (2016) An analysis of asymmetric consumer price responses and asymmetric cost pass-through in the French coffee market. European Review of Agricultural Economics, 43(5): 781-804.

Bronnenberg B, Kruger M, and Mela C (2008) Database paper: the IRI marketing data set. Marketing Science, 27(4): 745-748.

Carlson A (2008) Are consumers willing to pay more for Fair Trade certified TM coffee? Master's thesis, University of Notre Dame, Department of Economics.

Chiputwa B, Spielman D, and Qaim M (2015) Food standards, certification, and poverty among coffee farmers in Uganda. World Development, 66: 400-412.

Didier T and Lucie S (2008) Measuring consumer's willingness to pay for organic and Fair Trade products. International Journal of Consumer Studies, 32(5): 479-490.

Draganska M, Klapper D, and Villas-Boas S (2010) A larger slice or a larger pie? An empirical investigation of bargaining power in the distribution channel. Marketing Science, 29(1): 57-74.

Dragusanu R, Giovannucci D, and Nunn N (2014) The economics of Fair Trade. Journal of Economic Perspectives, 28(3): 217-36. 
Dragusanu R and Nunn N (2018) The effects of Fair Trade certification: evidence from coffee producers in Costa Rica. Working Paper, National Bureau of Economic Research.

Fair Trade USA (2017a) Agricultural production standard. Published March 1, 2017; Effective May 1, 2017. Version 1.0.0.

(2017b) Cost of sustainable production: an overview of farm-level production analyses in Latin America. Fair Trade USA Supply Chain Research, in cooperation with SC Johnson College of Business at Cornell University and David R. Atkinson Center.

Feuerstein S (2002) Do coffee roasters benefit from high prices of green coffee? International Journal of Industrial Organization, 20(1): 89-118.

FLO-Cert GmbH (2015) Fee system small producer organization. Version 26 / 01.01.2015.

Friedrichsen J and Engelmann D (2018) Who cares about social image? European Economic Review, 110: 61-77.

Gingrich C and King E (2012) Does fair trade fulfill the claims of its proponents? Measuring the global impact of fair trade on participating coffee farmers. Journal of Cooperatives, 26: 17-39.

Gitter S, Weber J, Barham B, Callenes M, and Valentine J (2012) Fair trade-organic coffee cooperatives, migration, and secondary schooling in Southern Mexico. The Journal of Development Studies, 48(3): 445-463.

Hainmueller J, Hiscox M. J, and Sequeira S (2015) Consumer demand for the fair trade label: evidence from a multi-store field experiment. Review of Economics and Statistics, 97(2): 242-256.

Information Resources Inc. (2015) IRI Academic Data Set. Data base and description (2001-2012).

de Janvry A, McIntosh C, and Sadoulet E (2015) Fair trade and free entry: can a disequilibrium market serve as a development tool? Review of Economics and Statistics, 97(3): $567-573$.

Johannessen S and Wilhite H (2010) Who really benefits from Fairtrade? An analysis of value distribution in Fairtrade coffee. Globalizations, 7(4): 525-544.

Lancaster K (1966) A new approach to consumer theory. Journal of Political Economy, 74(2): 132-157. 
Loureiro M and Lotade J (2005) Do fair trade and eco-labels in coffee wake up the consumer conscience? Ecological Economics, 53(1): 129-138.

Minten B, Dereje M, Engida E, and Tamru S (2018) Tracking the quality premium of certified coffee: evidence from Ethiopia. World Development, 101(Supplement C): $119-132$.

Munro A and Valente M (2016) Green goods: Are they good or bad news for the environment? Evidence from a laboratory experiment on impure public goods. Environmental and Resource Economics, 65(2): 317-335.

Nakamura E and Zerom D (2010) Accounting for incomplete pass-through. The Review of Economic Studies, 77(3): 1192-1230.

National Promotion Reports LLC. (2016) Price-Trak: wholesale coffee prices USA (20062012). Unpublished raw data.

Parrish B, Luzadis V, and Bentley W (2005) What Tanzania's coffee farmers can teach the world: a performance-based look at the fair trade-free trade debate. Sustainable Development, 13(3): 177-189.

Ponte S (2002) The 'latte revolution'? Regulation, markets and consumption in the global coffee chain. World Development, 30(7): 1099-1122.

Potts J, Lynch M, Wilkings A, Huppé G, Cunningham M, and Voora V (2014) The state of sustainability initiatives review 2014: standards and the green economy. Technical report, International Institute for Sustainable Development (IISD) and the International Institute for Environment and Development (IIED).

Reinstein D and Song J (2012) Efficient consumer altruism and fair trade products. Journal of Economics \& Management Strategy, 21(1): 213-241.

Ruben R and Fort R (2012) The impact of fair trade certification for coffee farmers in Peru. World Development, 40(3): 570-582.

Sáenz Segura F and Zúniga-Arias G (2008) Assessment of the effect of fair trade on smallholder producers in Costa Rica: a comparative study in the coffee sector. in The impact of Fair Trade by R. Ruben (ed.): 117-135: Wageningen Academic Publishers.

Schlippenbach V. v and Teichmann I (2012) The strategic use of private quality standards in food supply chains. American Journal of Agricultural Economics, 94(5): 1189-1201.

Smith S (2010) For love or money? Fairtrade business models in the UK supermarket sector. Journal of Business Ethics, 92: 257-266. 
Talbot J (2004) Grounds for agreement: The political economy of the coffee commodity chain: Rowman \& Littlefield Publishers.

Teyssier S, Etilé F, and Combris P (2014) Social-and self-image concerns in fair-trade consumption. European Review of Agricultural Economics, 42(4): 579-606.

Valkila J, Haaparanta P, and Niemi N (2010) Empowering coffee traders? The coffee value chain from Nicaraguan Fair Trade farmers to Finnish consumers. Journal of Business Ethics, 97(2): 257-270.

Valkila J and Nygren A (2010) Impacts of fair trade certification on coffee farmers, cooperatives, and laborers in Nicaragua. Agriculture and Human Values, 27(3): 321333.

Van Rijsbergen B, Elbers W, Ruben R, and Njuguna S (2016) The ambivalent impact of coffee certification on farmers' welfare: a matched panel approach for cooperatives in Central Kenya. World Development, 77: 277-292. 


\section{Appendix}

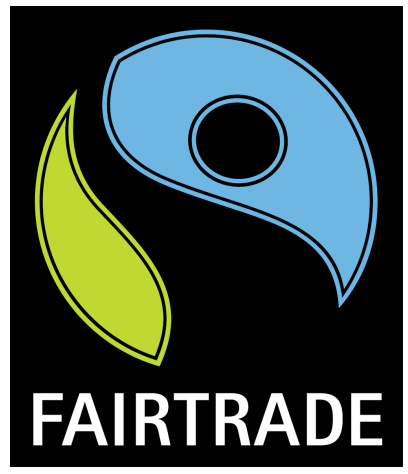

(a) FLO International logo

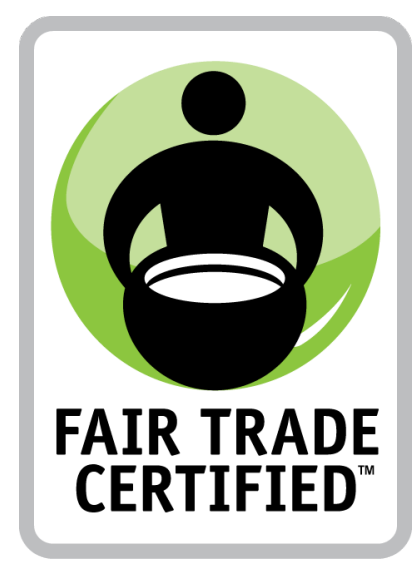

(b) Fair Trade USA logo (used on the products in this study)

Figure 7: Fairtrade logos

Source: www.fairtrade.net//and www.fairtradecertified.org/

\begin{tabular}{lcccc}
\hline \hline & $\begin{array}{c}\text { Matched } \\
(=\text { Kept })\end{array}$ & Dropped & Difference & \\
\hline Package size (in oz.) & 17.0 & 15.3 & 1.7 & $* * *$ \\
Retail price per unit & $\$ 6.66$ & $\$ 7.09$ & $-\$ 0.43$ & $* * *$ \\
Retail price per lb & $\$ 6.93$ & $\$ 8.34$ & $-\$ 1.41$ & $* * *$ \\
Fairtrade-certified & $3.15 \%$ & $3.12 \%$ & $0.02 \%$ & $* *$ \\
Decaffeinated & $17.92 \%$ & $15.71 \%$ & $2.21 \%$ & $* * *$ \\
\hline Observations & $3,187,863$ & $15,400,000$ & & \\
\hline \hline
\end{tabular}

Two-sided Welch t-test, unequal variances. Stars denote significance: ${ }^{* * *}$ means $p<0.01,{ }^{* *}$ means $p<0.05$.

Table 6: Data selection from matching IRI data and Price-Trak data (t-test) Source: full IRI data set with observations at UPC-week-store level, own computations. 


\begin{tabular}{lcccc}
\hline \hline & $\begin{array}{c}\text { Only one } \\
\text { type }\end{array}$ & $\begin{array}{c}\text { Both } \\
\text { Fairtrade } \\
\text { and con- } \\
\text { ventional }\end{array}$ & Difference & \\
\hline Package size (in oz.) & 16.4 & 11.4 & 5.1 & $* * *$ \\
Retail price per unit & $\$ 6.66$ & $\$ 7.47$ & $-\$ 0.82$ & $* * *$ \\
Retail price per lb & $\$ 7.08$ & $\$ 10.53$ & $-\$ 3.44$ & $* * *$ \\
Wholesale price per unit & $\$ 5.45$ & $\$ 6.01$ & $-\$ 0.56$ & $* * *$ \\
Wholesale price per lb & $\$ 5.59$ & $\$ 8.50$ & $-\$ 2.91$ & $* * *$ \\
Cooperative price per unit & $\$ 2.45$ & $\$ 1.86$ & $\$ 0.59$ & $* * *$ \\
Cooperative price per lb & $\$ 2.39$ & $\$ 2.61$ & $-\$ 0.22$ & $* * *$ \\
Fairtrade-certified & $2.62 \%$ & $55.84 \%$ & $-53.22 \%$ & $* * *$ \\
Organic & $0.01 \%$ & $6.91 \%$ & $-6.90 \%$ & $* * *$ \\
Decaffeinated & $19.56 \%$ & $14.94 \%$ & $4.62 \%$ & $* * *$ \\
\hline Observations & $1,778,459$ & 96,273 & & \\
\hline \hline
\end{tabular}

Two-sided Welch t-test, unequal variances. Stars denote significance: ${ }^{* * *}$ means $p<0.01$.

Table 7: Comparison of companies offering both Fairtrade-certified and conventional coffee and other companies (t-test)

Source: main data set with observations at UPC-week-store level, own computations. 


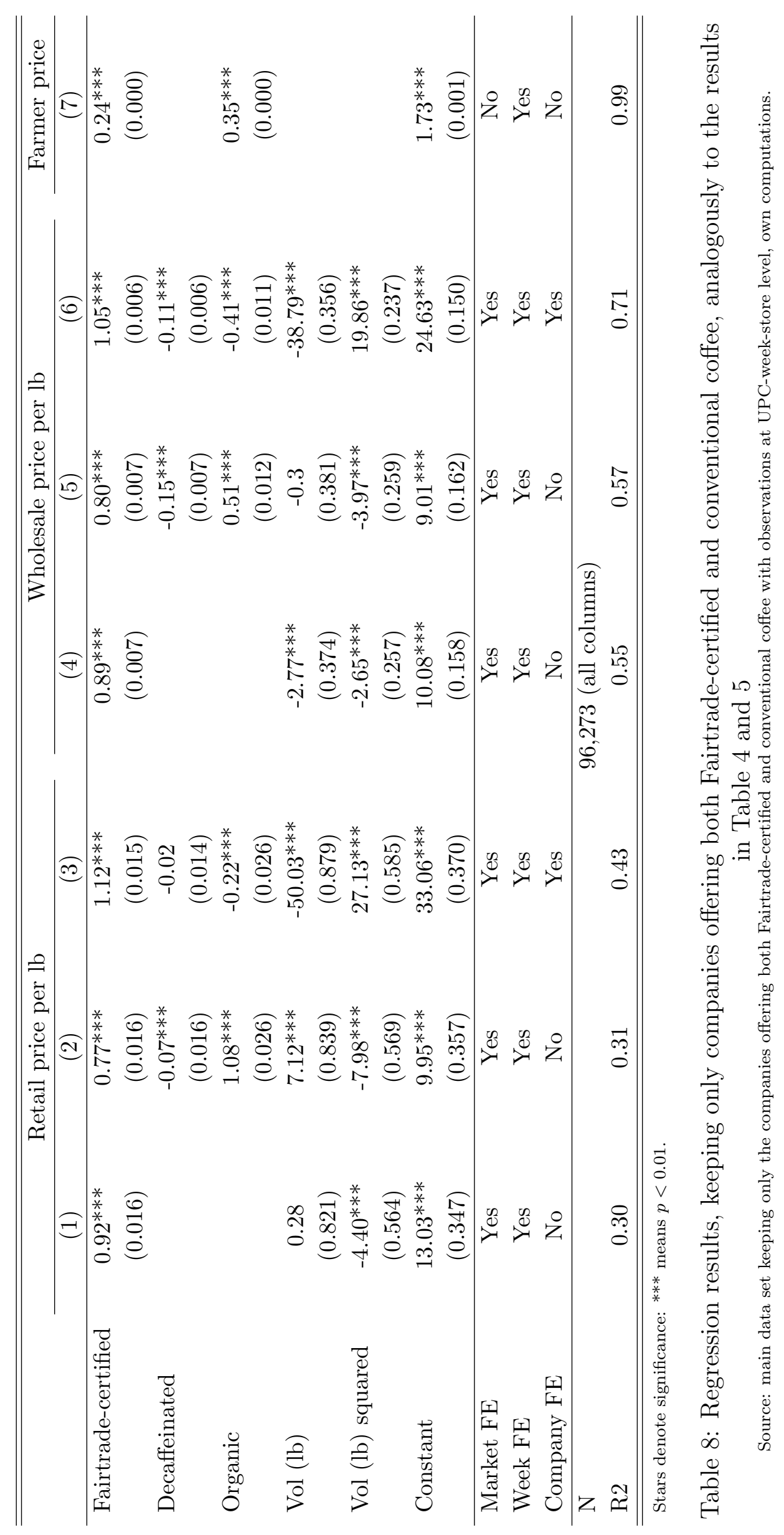

